\title{
PERENCANAAN BISNIS KERIPIK BIJI DURIAN (STUDI KASUS : KOTA AMBON)
}

\author{
A. L. Kakerissa \\ Program Studi Teknik Industri, Fakultas Teknik Universitas Pattimura, Ambon \\ S. Titaley \\ Program Studi Teknik Industri, Fakultas Teknik Universitas Pattimura, Ambon \\ Muhamad Jufri \\ Program Studi Teknik Industri, Fakultas Teknik Universitas Pattimura, Ambon
}

\begin{abstract}
ABSTRAK
Durian merupakan salah satu tanaman yang memiliki banyak manfaat dan juga dapat diolah menjadi berbagai jenis produk yang dapat menambah nilai ekonomis untuk dikembangkan di Kota Ambon. Karena itu, pengembangan usaha Keripik biji durian akan memiliki prospek dan sasaran pasar yang bagus. Bisnis ini membutuhkan suatu alat yang dapat dengan mudah memberikan informasi mengenai komoditi tersebut dan dapat membuat para calon investor untuk menentukan perencanaan bisnis yang sesuai untuk dijalankan pada bidang ini. Oleh karena itu, diperlukan suatu paket model berisi perencanaan bisnis (Business Plan) yang dirancang untuk membantu para calon investor dalam pengambilan keputusan secara cepat, tepat, dan efisien atas perencanaan bisnis. Perancangan proses Business Plan dilakukan untuk membantu analisis Break Even Point dan Pay Back Periode (PBP), yang akan menentukan layak studi kelayakan usaha, potensi pasar industri keripik biji durian sangat terbuka, lokasi yang dipilih untuk industri ini adalah Kota Ambon dengan pertimbangan tertentu. Berdasarkan perhitungan biaya dan kapasitas produksi, maka harga jual keripik biji durian adalah Rp. 6.000/saset, kapasitas produksi total 4.133 saset/bulan dengan tenaga kerja 4 orang. Berdasarkan analisis finansial, Titik pulang pokok terjadi pada total produksi sebanyak 1.469 saset, Waktu pengembalian investasi sangat kecil yaitu hanya 1 bulan sehingga dapat disimpulkan bahwa industri keripik biji durian ini layak direalisasikan.
\end{abstract}

Kata Kunci : Perencanaan Bisnis, Biji Durian, Keripik

\section{ABSTRACT}

Durian is a plant with many benefits that might be processed into various types of economically products in Ambon City. The development of durian seed chips business will have good prospects and target markets. This business needs a tool that be able to easily provide information about these commodities and make potential investors to determine the appropriate business plan. Therefore, we need a package model containing a business plan (Business Plan) that is designed to assist potential investors in making decisions quickly, precisely, and efficiently for business planning. The Business Plan process design is carried out to assist the analysis of Break Even Point and Pay Back Period $(P B P)$, which will determine the business feasibility. A market potential of the durian seed chip industry is very open. A location chosen for this industry is Ambon City with certain considerations. Based on the calculation of cost and production capacity, the selling price of durian seed chips is Rp. 6,000 / sachets, total production capacity of 4,133 sachets / month with a workforce of 4 people. Based on financial analysis, the principal return point occurred in a total production of 1,469 sachets. The investment payback period was very small at only 1 month so it can be concluded that the durian seed chip industry is feasible.

Kata Kunci : Business Plan, Durian Seeds, Chips.

\section{PENDAHULUAN}

Buah durian termasuk buah musiman. Musim berbuahnya tergantung lingkungan tempat tumbuhnya. Di Provinsi Maluku misalnya, musim buah utama dimulai dari bulan april sampai mei sedangkan untuk periode juny sampai juli itu buahnya lebih sedikit. Daerah-daerah yang banyak 
memproduksi durian yaitu terletak pada daerah, kabupaten maluku tengah, kabupaten seram bagian barat, kabupaten seram bagian timur, dan kota ambon (sumber: BPS Provinsi Maluku 2016).

Produksi durian di daerah ini cukup melimpah. Data Biro Pusat Statisktik (2016) menunjukkan bahwa produksi durian mencapai 4.627 ton per tahun(sumber: BPS dan Direktorat Jenderal Hortikultura). Sedangkan di wilayah Kota Ambon dengan jumlah lebih dari 500 pohon dan tingkat produksi 76-87 qu per triwulan. Sehingga tidak heran banyak masyarakat yang beralih profesi sebagai pedagang durian. Selama ini, bagian buah durian yang lebih umum dikonsumsi adalah bagian dagingnya. Presentase berat bagian ini termasuk rendah yaitu hanya 20-35\%. Hal ini berarti kulit (60-75\%) dan biji (5-15\%) belum termanfaatkan secara maksimal (Wahyono, 2009).

Hasil pengamatan di beberapa pusat di Kota Ambon, misalnya pantai losari mardika dan depan ACC, harga 1 buah durian dijual dengan harga berkisar Rp.10.000-Rp.25.000 per buah, dengan rata rata biji per buah durian hasil pendataan adalah 14 biji per buah durian. Khusus untuk biji buah durian maka berdasarkan hasil penelitian awal di kota Ambon pada beberapa tempat seperti pantai losari mardika dan di depan ACC bahwa ditemukan rata-rata biji pada setiap buah itu adalah 14 biji per buah. Jika kita mengacu kepada data BPS tahun 2016 untuk panen durian maka kemungkinan akan terdapat biji sebanyak 1.19.168 biji durian di kota Ambon. Biji ini seluruhnya menjadi limbah yang dibuang tidak dikonsumsi lagi. Biasanya biji durian hanya dikonsumsi sebagian kecil masyarakat setelah direbus atau dibakar, padahal biji durian dapat diolah menjadi makanan lain yang lebih menarik dan enak. Produk pengolahan biji durian antara lain keripik biji durian, bubur biji durian dan tepung biji durian (Umat, 2013). Dalam memproduksi suatu barang jadi untuk dipasarkan hal yang paling utama sebelum barang itu diproduksi adalah pengetahuan tentang pasar terhadap potensi dan keinginan pasar terhadap produk dimaksud (keripik biji durian), oleh karena itu mengakhiri pendidikan penulis pada program study Teknik Industri, penulis selanjutnya mengangkat persoalan produksi dan kelayakan usaha keripik biji durian untuk menjadi suatu paket penelitian dengan judul Perencanaan bisnis keripik biji durian.

Penelitian ini bertujuan untuk membuat rancangan atau desain bisnis keripik biji durian dan analisis kelayakan finansial bisnis keripik biji durian.

\section{LANDASAN TEORI}

\section{Tinjauan Umum Tanaman Durian}

Durian (Durio zibethinus Murr) merupakan salah satu tanaman hasil perkebunan yang telah lama dikenal oleh masyarakat yang pada umumnya dimanfaatkan sebagai buah saja. Sebagian sumber literatur menyebutkan tanaman Durian adalah salah satu jenis buah tropis asli Indonesia (Rukmana, 1996). Dalam dunia tumbuh - tumbuhan, maka buah durian bisa digolongkan sebagai berikut :

$\begin{array}{ll}\text { - Kerajaan } & \text { : Plantae(tumbuhan) } \\ \text { - Devisi } & \text { : Spermatophyta (tumbuhan berbiji) } \\ \text { - Sub devisi } & \text { : Angiospermae (berbiji tertutup) } \\ \text { - Kelas } & : \text { Dicotyledonae (berkeping dua) } \\ \text { - Ordo } & \text { :Malvaceae } \\ \text { - Famili (keluarga) } & : \text { Bombaceae } \\ \text { - Genus } & : \text { Durio } \\ \text { - Species (jenis) } & : \text { Durio zibethinus Murr (Wikipedia, 2009). }\end{array}$

Daftar Kandungan Gizi Buah Durian

\begin{tabular}{|c|c|c|}
\hline \multirow{2}{*}{ Kandungan Gizi } & \multicolumn{2}{|c|}{ Nilai Rata - Rata Buah Durian } \\
\hline & Satuan & .Tumlah \\
\hline air $(\%)$ & Gr & 65 \\
\hline protein $(\%)$ & Gr & 9,79 \\
\hline lemak $(\%)$ & Gr & 3 \\
\hline karbohidrat (\%) & Gr & 30 \\
\hline energi $(\%)$ & Kal & 134 \\
\hline Kalium (\%) & $\mathrm{Mg}$ & 436 \\
\hline Kalsium (\%) & Mgr & 0,27 \\
\hline fosfor $(\%)$ & Mgr & 0.9 \\
\hline Serat (\%) & $\mathrm{Gr}$ & 1.4 \\
\hline vitamin a & $\mathrm{S}_{1}$ & 175 \\
\hline Vitamin b1 $(\mathrm{mg} / 100 \mathrm{~g})$ & Mgr & 0.1 \\
\hline Vitamin b2 (mg/100g) & - & - \\
\hline Vitamin c (mg/100g) & Mgr & 53 \\
\hline Bagian dapat dimakan & $\%$ & 22 \\
\hline
\end{tabular}


Kandungan Biji Durian memiliki kandungan pati cukup tinggi dan berpotensi sebagai alternatif pengganti makanan (dapat dibuat bubur yang dicampur daging buahnya), kulit dipakai sebagai bahan abu gosok yang bagus, dengan cara dijemur sampai kering dan dibakar sampai hancur. Potensi dan Kandungan Nutrisi Biji Durian selain sebagai makanan buah segar dan olahan lainnya, terdapat manfaat dari bagian lainnya, yaitu: tanamannya sebagai pencegah erosi di lahan- lahan yang miring, batangnya untuk bahan bangunan/perkakas rumah tangga, kayu, durian setaraf dengan kayu sengon sebab kayunya cenderung lurus (Tambun, 2012). Bijinya durian dapat direbus atau dibakar dan dapat dijadikan cemilan sehat karena mengandung pati yang sangat tinggi. Tapi perlu diingat, tidak diperbolehkan memakan biji mentah dari buah yang berasal dari genus Durio ini, karena asam lemak siklopropena (cyclopropene) yang terkandung dalam biji durian bersifat racun bagi tubuh.Biji durian juga dapat diolah sebagai campuran tablet, yaitu biji durian dikeringkan kemudian dibuat pati dengan menggunakan metoda ekstraksi. Pengertian metoda ekstraksi adalah salah satu cara menghaluskan bahan sampai berukuran sangat kecil sehingga menyerupai debu halus (Bakti, 2012). Khasiat Biji Durian yaitu mengandung protein, karbohidrat, lemak, kalsium dan fosfor sehingga dimungkinkan dapat diolah menjadi produk pangan. Banyak produk yang sebenarnya dapat dihasilkan dari biji durian. Pembuatan tepung biji durian juga dapat dihasilkan sebagai substitusi tepung terigu, selain itu biji durian dapat diolah menjadi keripik. Saat ini keripik dari biji durian belum banyak beredar di pasaran sehingga diharapkan dengan pengolahan biji durian dapat memberikan nilai tambah dan meningkatkan pendapatan petani durian. Pengolahan biji durian digunakan sebagai campuran tablet, yaitu biji durian dikeringkan kemudian dibuat pati dengan menggunakan metoda ekstraksi. Pengertian Metoda ekstraksi adalah salah satu cara menghaluskan bahan sampai berukuran sangat kecil sehingga menyerupai debu halus (Bima, 2012).

\section{Keripik}

Keripik merupakan makanan tradisional yang diperoleh dengan cara menggoreng bahan yang telah mengalami perlakuan pendahuluan ke dalam minyak panas. Keripik adalah makanan ringan (snack food) yang tergolong jenis makanan crackers, yaitu makanan yang bersifat kering, renyah (crispy).Renyah adalah keras tetapi mudah patah. Sifat renyah, tahan lama, praktis, mudah dibawa dan disimpan, serta dapat dinikmati kapan saja terutama santai sambil membaca atau menonton televisi(Sulistyowati, 2000).

\section{Business Plan}

Bisnis adalah kegiatan atau usaha yang dilakukan untuk memperoleh keuntungan sesuai dengan tujuan dan target yang diiginkan dalam berbagai bidang, terutama bagi pemilik bisnis. Bentuk keuntungan yang diharapkan lebih banyak dalam bentuk finansial (Kasmir dan Fakfar,2007 dalam Wibowo, 2011). Brown dan Pertrello (1976) mendefenisikan bisnis sebagai suatu lembaga yang menghasilkan barang dan jasa yang menghasilkan barang dan jasa yang dibutuhkan oleh masyarakat. Apabila kebutuhan masyarakat meningkat maka lembaga bisnis pun akan meningkatkan pula perkembangannya untuk memenuhi kebutuhan tersebut.

Satu tahap penting dalam pendirian setiap bisnis baru adalah penyusunan sebuah rencana bisnis menurut (Rangkuti, 2005 dalam Wibowo, 2011), perencanaan bisnis merupakan alat yang sangat penting bagi pengusaha maupun pengambilan keputusan kebijakan perusahaan. Tujuan perencanaan bisnis adalah agar kegiatan bisnis yang akan dilaksanakan maupun sedang berjalan tetap berada di jalur yang benar sesuai dengan yang direncanakan. Perencanaan bisnis juga digunakan sebagai pedoman untuk mempetajam rencana-rencana yang diharapkan, karena di dalam perencanaan bisnis, posisi perusahaan, arah tujuan perusahaan dan cara mencapai sasaran yang ingin dicapai dapat diketahui.

Djamin (1992) dalam Mochammad Iqbal Ardi Wibowo (2011) juga menambahkan alasan yang dapat dikemukakan akan betapa pentingnya suatu proyek sebelum dilaksanakan harus terlebih dahulu direncanakan dengan seksama antara lain sebagai berikut :

1. Dengan adanya perencanaan diharapkan terdapatnya suatu pengarah kegiatan, adanya pedoman bagi pelaksanaan kegiatan yang ditujukan pada pencapaian tujuan.

2. Dengan perencanaan maka dilakukan suatu perkiraan terhadap hal-hal dalam masa pelaksanaan yang akan dilalui. Perkiraan dilakukan mengenai potensi dan prospek perkembangan, juga mengenai hambatan dan resiko yang mungkin dihadapi. Perencanaan menguasahakan agar ketidakpastian dapat dibatasi sekecil mungkin.

3. Perencanaan memberikan kesempatan untuk memilih berbagai alternatif tentang cara yang terbaik atau kesempatan untuk memilih kombinasi cara yang terbaik. 
4. Dengan perencanaan dilakukan penyusunan sakla prioritas, memilih urutan- urutan dari segi pentingnya suatu tujuan, sasaran maupun kegiatan usahanya.

5. Dengan adanya rencana maka akan asa suatu alat ukur atau standar untuk mengadakan pengawasan/evaluasi.

6. Dengan adanya perencanaan pengguna dan alokas sumber-sumber pembangunan yang terbatas adanya dapat dimanfaatkan secara lebih efisisen dan efektif, diusahakan dihindarinya pemborosan. Suatu usaha untuk mencapai hasil secara maksimal dengan penggunaan sumber yang tesedia.

Tujuan rencana bisnis menurut Pinson (2003) dalam Mochammad Iqbal Ardi Wibowo (2011), adalah sebagai berikut:

1. Sebagai panduan

2. Sebagai dokumentasi pendanaan

3. Memperluar ke pasar luar negeri.

\section{Investasi}

Dalam analisis privat, yang tergolong biaya investasi pada tahap permulaan proyek hanyalah yang dibiayai dengan modal saham simpanan modal sendiri. Tidak termasuk pinjaman atau bantuan dari dalam maupun luar negeri. Dalam analisis ekonomi dengan suatu pengecualian seluruh biaya investasi, apakah dibiayai dengan modal yang dibiayai dengan pinjaman dari dalam maupun luar, dengan modal saham atau pinjaman, dianggap sebagai biaya proyek pada saat dikeluarkan.

1. Investasi Dan Bunga

Investasi (I) merupakan modal yang diperlukan untuk pembangunan (rehabilitasi, Perluasan) suatu proyek di tambah dengan bunga (i\%) selama pembangunan (during construction), yaitu :

$$
\mathrm{I}=\text { modal }+(\mathrm{i} \% \mathrm{x} \text { Modal })
$$

2. Biaya Investasi

Biaya investasi ( cost of investment adalah biaya atas proyek tersebut tiap- tiap tahun yang meliputi:

a. Bunga atas investasi (dihitung sejak proyek selesai dibangun), yaitu bunga atas investasi $=\mathrm{a} \%$

$\mathrm{x}$ I ( $\mathrm{a} \%$ adalah presentasi bunga

b. Operation cost atas proyek $(\mathrm{O})$

c. Maintenance cost atas proyek (M)

d. Replacement atas peralatan proyek

Biaya- biaya yang berhubungan dengan produksi maupun distribusi (supplay) produksi dan biaya lain yang berhubungan dengan produksi tidak masuk dalam biaya investasi.

Biaya overhead dapat dimasukan kedalam biaya investasi atau biaya produksi tergantung kebijakan manajemen perusahaan.

\section{Cashflow}

Cashflow merupakan jumlah pengeluaran (pembayaran) tiap periode antara lain pembelian bahan, peralatan, dll disamping penerimaan.

4. Investasi Lanjutan

Investasi lanjutan adalah investasi yang diperlukan untuk perluasan atau rehabilitasi suatu perusahaan yang sudah ada atau menciptakan produk dengan tujuan meningkatkan kesehjateraan pemilik, meningkatkan value, memperluar lapangan kerja dan menambah penghasilan negara.

5. Kebutuhan Investasi

Kebutuhan investasi untuk barang-barang modal, harta tak berwujud, dan harta lancer.

\section{Studi Kelayakan Bisnis}

Sutojo (2000) dan kadariah et al (1999) dalam Mochammad Iqbal Ardi Wibowo (2011), menyebutkan bahwa kajian terhadap keadaan dan prospek suatu pabrik dilakukan atas aspek-aspek tertentu, yaitu aspek teknis, aspek manajerial dan administratif, aspek organisasi, aspek pemasaran, aspek finansial, dan aspek ekonomi. (Umar, 2005 dalam Mochammad Iqbal Ardi Wibowo, 2011) menambahkan bahwa kajian terhadap keadaan dan prospek suatu pabrik juga memerlukan analisis terhadap aspek lingkungan, aspek legalitas, dan aspek sosiakl ekonomi. Aspek-aspek tersebut biasanya dianalisis dengan teknik-teknik tertentu dengan mempertimbangkan manfaat bagi industri tersebut.

1. Aspek Pasar Dan Pemasaran

Aspek pasar dan pemasaran dikaji untuk mengungkapkan permintaan penawaran, harga program pemasaran, dan perkiraan penjualan yang dapt dicapai oleh prusahaan, atau pangsa pasar yang dapat dikuasai oleh perusahaan. Selain itu, analisis terhadap pasar dan pemasaran pada suatu usulan proyek 
ditujukan untuk mendapatkan gambaran tentang potensi pasar bagi produk yang tersedia untuk masa yang akan datang, dan menentukan jenis stratefi pemasaran yang digunakan guna mencapai pangsa pasar yang telah ditetapkan (Husnan dan Suwarsono, 2000 dalam Mochammad Iqbal Ardi Wibowo, 2011).

2. Aspek Teknis Atau Operasi

Aspek teknik dan teknologi merupakan salah satu aspek penting bagi proyek karena merupakan jawaban dari pertanyaan dapat tidak produk tersebut dibuat. Hal ini sangat dirasakan jika bidang usaha yang digunakan bersifat manufacturing atau poros intinya adalah teknologi (Sutojo, 2000 dalam Mochammad Iqbal Ardi Wibowo, 2011). Evaluasi aspek teknis dan operasi meliputi hal-hal berikut ini:

a. Penentuan lokasi proyek.

b. Penentuan kapasitas produksi ekonomis yang merupakan volume atau jumlah satuan produk yang dihasilkan selama waktu tertentu.

c. Pemilihan teknologi yang tepat dipengaruhi oleh kemungkinan pengadaan tenaga ahli, bahan baku dan bahan pembantu, kondisi alam dan lainnya tergantung proyek yang didirikan.

d. Penentuan proses produksi yang dilakukan dan tata letak pabrik yang dipilih, termasuk tata letak bangunan dan fasilitas lain.

3. Aspek Keuangan

Aspek ekonomi dan keuangan merupakan aspek yang menentukan kalayakan usaha dilihat dari segi ekonomi dan keuangan. Jika sebuah gagasan usaha yang direncanakan telah layak dilihat dari aspek pemasaran dan teknis produksi, langkah selanjutnya adalah mengadakan penilaian dari aspek ekonomi dan keuangan. Pembahasan yang dilakukan menyangkut dengan biaya investasi.

Modal kerja, biaya operasi dan pemeliharaan, sumber pembiayaan, perhitungan pendapatan yang mungkin diterima, serta perhitungan kriteria investasi. Selain itu, dalam aspek ini juga dibahas mengenai proyeksi laba/rugi yang bertujuan untuk mengetahui posisi keuangan dari usaha yang akan dilaksanakan (Ibrahim, 2003 dan Mochammad Iqbal Ardi Wibowo, 2011).

Aspek-aspek yang digunakan dalam rencana keuangan meliputi asumsi perhitungan finansial, biaya investasi, prakiraan harga dan penerimaan, proyeksi laba dan rugi, titik pulang pokok (BEP), dan waktu pengembalian investasi $(\mathrm{PbP})$.

\section{METODE PENELITIAN}

\section{Variabel dan Definisi Operasional}

Variabel keputusan dapat dinotasikan dengan lambang X. Yang termasuk dalam indikator variabel keputusan dalam penilitian adalah sebagai berikut :

a. Biaya Investasi $\left(\mathrm{X}_{1}\right)$

b. Biaya Produksi $\left(\mathrm{X}_{2}\right)$

Variabel keputusan merupakan suatu indikator untuk mencapai variabel tujuan. Yang mana variabel tujuan adalah Keuntungan Dari Keripik Biji Durian.

\section{Metode Analisa Data}

Metode analisa data yang digunakan dalam penelitian ini adalah metode Bussines Plan. Kemudian dilakukan pengolahan data dengan melakukan analisa kelayakan finansial.

Berikut ini merupakan flowchart dari penelitian ini. 


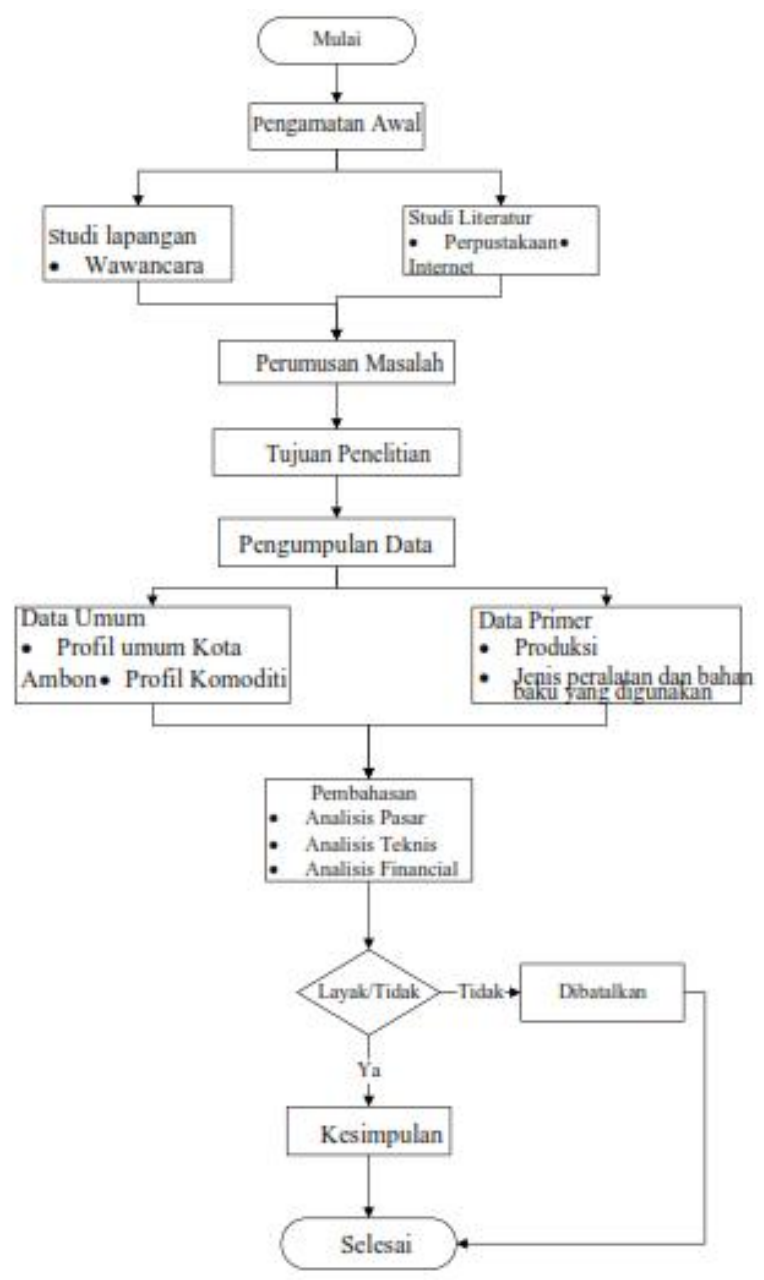

Flowchart Penelitian

HASIL DAN PEMBAHASAN

Rata-rata Produksi Biji Durian/Triwulan Di Kota Ambon

Rata-rata Produksi Biji Durian/Triwulan Di Kota Ambon Tahun 2018

\begin{tabular}{|c|c|c|c|c|c|}
\hline \multirow{2}{*}{$\begin{array}{l}\text { No. } \\
\text { Urut }\end{array}$} & \multirow{2}{*}{$\begin{array}{c}\text { Nama } \\
\text { Durian }\end{array}$} & \multicolumn{2}{|c|}{ Ukuran Buah } & \multirow{2}{*}{$\begin{array}{c}\text { Berat } \\
\text { Buah/Kg }\end{array}$} & \multirow{2}{*}{$\underset{\text { Biji }}{\text { Jumlah }}$} \\
\hline & & Diameter & Panjang & & \\
\hline 1 & Tuny & 15 & 22 & 0,75 & 13 \\
\hline 2 & Bangkok & 18 & 19 & 0,8 & 13 \\
\hline 3 & Bangkok & 18,2 & 20 & 0,9 & 11 \\
\hline 4 & Bangkok & 18,5 & 21 & 0,15 & 12 \\
\hline 5 & Bangkok & 19 & 22 & 0,22 & 13 \\
\hline 6 & Tuny & 15,2 & 22,2 & 0,76 & 15 \\
\hline 7 & Tuny & 15,3 & 22,3 & 0,77 & 14 \\
\hline 8 & Tuny & 15,4 & 22,4 & 0,78 & 14 \\
\hline 9 & Tuny & 15,5 & 22,5 & 0,79 & 15 \\
\hline 10 & Tuny & 15,6 & 22,6 & 0,82 & 15 \\
\hline \multicolumn{2}{|c|}{ Rata-Rata } & 16,57 & 21,6 & 0,674 & 13,5 \\
\hline
\end{tabular}

Rata-rata produksi biji durian/buah durian adalah 14 biji/buah setelah digenapkan. Total produksi buah durian untuk pulau ambon dan pasokan pulau seram untuk kebutuhan 3 bulan pada musim panen 
500 pohon dipulau Ambon, dengan rata-rata produksi durian/pohon 75 buah((70-80) /pohon). Dengan

demikian untuk pulau Ambon produksi biji durian per triwulan

$$
\begin{aligned}
& =500+75 \times 14 \\
& =1.550 \text { Biji Durian }
\end{aligned}
$$

\section{Pasokan Buah Durian Asal Pulau Seram}

Pasokan buah durian untuk waktu 3 bulan pada musim panen durian. Rata- rata per hari 2 truk dengan isi muatan buah durian per truk \pm 300 buah/truk dengan demikian buah durian per hari 600 buah, dengan menggunakan potensi biji per buah seperti pada tabel di atas yaitu 14 biji/buah.

$=600 \times 14$

$=8.400$ biji durian

Sehingga total produksi biji durian/triwulan

$=90 \times 8.400$

$=756.000$ biji durian

Dengan demikian total biji durian di kota ambon/triwulan

$=1.550+756.000$

$=757.550$ biji durian

Potensi biji durian/bulan

$=757.550 / 3$ bulan

= 252.516/bulan

Analisis Pasar Dan Pemasaran

1. Analisa Pasar

A. Segmentasi

a) Geografi

Produk keripik biji durian merupakan produk yang diproduksi secara langsung dan dijual kepada pelanggan. Semua orang dapat menjadi konsumen produk ini. Berdasarkan publikasi BPS, pada bulan Desember 2016, jumlah penduduk Kota Ambon sebanyak 427.934 jiwa. Segmentasi pasar produk keripik biji durian ini adalah masyarakat luas yang berperan sebagai konsumen yang menyukai keripik khusunya keripik biji durian sebagai makanan ringan yang sehat dan bergizi, dengan variabel segmentasi yang digunakan adalah wilayah negara karena produk keripik biji durian ini lebih mengacu dipasarkan didalam negeri. Keripik biji durian ini akan dipasarkan di 7 wilayah Kota Ambon.

b) Demografi

Secara demografi keripik biji durian menargetkan konsumen di Kota Ambon dibagi menjadi kelompok-kelompok menurut jenis kelamin yaitu laki-laki dan perempuan serta kolompok menurut usia yang menyukai produk olahan keripik khusunya keripik biji durian, yaitu anak-anak berkisar 5-9 tahun, remaja berkisar 10-19 tahun, dan dewasa berkisar 20-60 tahun.

c) Psikografi Dan Gaya Hidup

Menentukan segmentasi berdasarkan psikografis sama dengan mengetahui perilaku konsumen sehingga dalam menentukan segmentasi psikografis ada beberapa item yaitu tempat belanja, motivasi membeli barang dan pola pembelian.

Dari hasil analisa pencatatan di lapangan terhadap 7 wilayah pemasaran (Batu merah, kebun cengkeh, galunggung, mardika, silale, jalan baru,dan terminal mardika) dari hasil presentasi konsumen atau serapan terhadap total pasokan per kios, dengan rata-rata serapan keripik sebesar $69 \%$ dari total stok saset keripik yang dipasarkan dalam masing masing wilayah yaitu sebesar $\mathbf{1 . 3 1 0}$ saset, dengan rata-rata pasokan per kios/wilayah sebesar 20 saset keripik untuk berbagai rasa. Dengan memperhatikan potensi serapan produk keripik untuk 7 wilayah pemasaran yang dapat dikatakan ke 7 wilayah pemasaran tersebut diatas mewakili pasar penjualan di kota Ambon maka sudah dapat kita gunakan sebagai dasar analisa total kebutuhan bahan baku, bahan tambahan-tambahan dan analisis pendapatan dari produksi keripik

B. Targeting

Targeting merupakan tahap lanjutan dari segmentasi pasar. Dalam menargetkan pasar produk keripik biji durian segmentasi menjadi acuan utamanya, dari analisis segmentasi, target pasar produk ini adalah semua kalangan yang menyukai produk olahan keripik biji durian dengan range umur 5-60 tahun dan bertempat tinggal di Kota Ambon

C. Positioning 
Posisi usaha produk keripik biji durian ini termasuk dalam posisi dimana belum ada pesaing dengan produk sejenis keripik biji durian dan juga produk hasil olahan durian lainnya. Sejauh ini produk keripik biji durian menjadi satu-satunya produk keripik yang berasal dari biji durian. Selain itu, produk ini juga dapat dikategorikan sebagai makanan ringan yang memiliki kandungan gizi yang baik untuk tubuh. Keunggulan inilah yang dapat membuat produk keripik biji durian ini memiliki nilai lebih dibandingkan pesaing lainnya.

D. Cara Pemasaran

Keripik biji durian dapat dipasarkan dengan cara order pemesanan. Hal ini biasanya untuk pemesanan partai yang agak besar, dalam hal ini dilakukan oleh distributor. Lebih jauh lagi, dengan pengemasan yang berstandar tinggi, produk keripik biji durian ini dapat menembus pemasaran di super market ataupun bahkan skala ekspor ke luar negeri. Dengan kemasan yang dibuat sedemikian rupa hingga dapat terlihat elegan, maka kalangan atas yang biasanya mempertimbangkan gengsi, tidak akan ragu untuk membeli keripik biji durian yang bersangkutan walaupun harga jualnya jadi akan lebih membengkak

Cara lain pemasaran keripik biji durian ini dengan cara menawarkan ke kios kios, warung dan toko-toko sembako yang berada di wilayah pemukiman seuai dengan stok/pasokan yang diinginkan oleh masing- masing kios,warung atau toko seperti pada hasil pencatatan di atas.

\section{Analisa Pemasaran}

Dari total serapan pasar di 7 wilayah pemasaran dalam kota Ambon sebanyak 908 saset ternyata konsumen lebih cenderung untuk mencicipi keripik rasa pedas yaitu sebesar 39,42\%, rasa manis 31,1\%, dan rasa asin sebesar 29,4\%. Besar serapan pasar di atas adalah untuk waktu penjualan 6 hari (seminggu). Dengan demikian target produksi keripik akan di utamakan dengan rasa pedas melihat kepada potensi serapan pasar untuk keripik rasa pedas banyak diminati.

A. Strategi Produk Keripik Biji Durian

Produk yang akan dipasarkan adalah keripik biji durian dengan bahan dasar biji durian. Produk ini dibentuk dalam ukuran kemasan 250 gram/kemasan dengan rasa yang berbeda (manis, asin, pedas). Hasil pencatatan keinginan konsumen dari data penjualan keripik pada kios warung maupun toko-toko kecil ternyata produk dengan rasa pedas $39,42 \%$ diminati oleh konsumen, dan sisanya untuk produk rasa manis dan asin .

\section{B. Strategi Harga Keripik Biji Durian}

Untuk menetapkan harga keripik biji durian digunakan harga keripik yang disesuaikan dengan harga pasar saat ini terhadap produk keripik. Dengan tetap memperhitungkan modal usaha, biaya produksi dan besar keuntungan. Harga pokok produksi dan harga jual ideal per saset keripik biji durian akan di analisa pada analisa harga pokok produksi.

C. Strategi Promosi

a) Merk Dagang

Keripik biji durian ini dipasarkan dengan menggunakan merk dagang "The king of chips" yang akan di lebelkan pada kemasan produk dengan warna yang nampak jelas dilihat dan menarik selain ditambahkan kemasan gambar buah durian, Nama The king of chips diambil dari bahasa inggris yang berarti raja keripik, dikarenakan durian merupakan raja dari buah-buahan.

b) Label

Label merupakan bagian dari kemasan yang menunjukkan identitas dari produk yang akan ditawarkan. Label tersebut akan digambarkan buah durian (biji) sebagai bahan dasar pembuatan keripik biji durian.

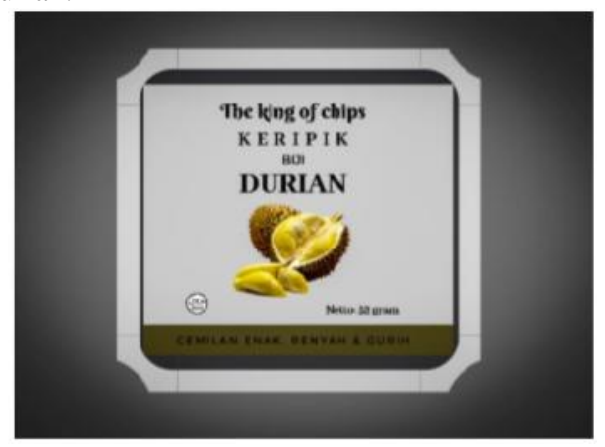

Label Kemasan Keripik Biji Durian 
c) Kemasan

Kemasan yang digunakan untuk produk ini adalah plastik pembungkus biasa. Dengan ukuran panjang $9 \mathrm{~cm}$ dan lebar $7 \mathrm{~cm}$ Panjang dan lebar kemasan keripik biji durian dirancang dengan ukuran tersebut untuk memungkin kan nama keripik dan gambar bahan baku keripik dapat terlihat dengan jelas, sebagai salah satu strategi pemasaran.

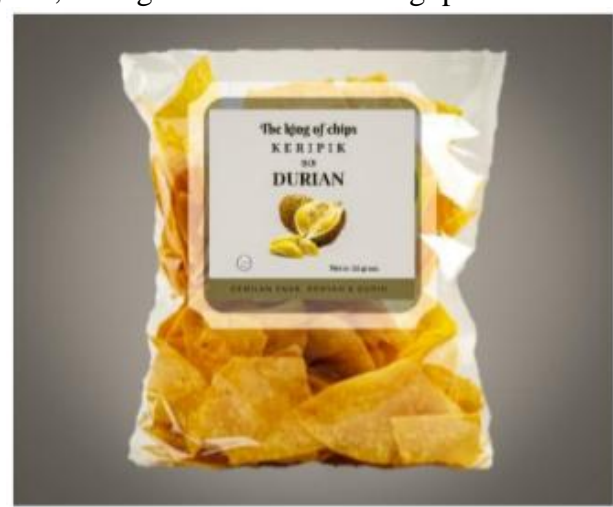

Kemasan Keripik Biji Durian

D. Strategi Distribusi Keripik Biji Durian

Alternatif saluran pemasaran yang dapat digunakan dalam memasarkan keripik biji durian melalui distributor industri pada wilayah Kota Ambon. Produk yang dihasilkan berupa keripik biji durian akan dipasarkan dengan cara penitipan ke pengecer (berupa warung atau toko makanan maupun toko biasa). Selain itu keripik biji durian yang dihasilkan dapat dipasarkan melalui door to door langsung ke konsumen akhir. Keripik biji durian dapat juga dipasarkan dengan dengan cara dimana produk keripik sudah dimasukan kedalam kantong-kantong berisikan 10 saset,15 saset, 20 saset, 25 saset dan 30 saset. Produk keripik biji durian ini selanjutnya diantarkan oleh seorang tenag kerja dengan menggunakan kendaraan bermotor (roda dua/ roda tiga). Hal ini biasanya untuk pemesanan partai yang agak besar, dalam hal ini dilakukan oleh distributor dengan terlebih dahulu menerima kepastian jumlah pesanan, nama pemesan, alamat pemesan, dan selanjutnya produk akan diantarkan kepada pemesan dengan waktu kurang dari 3 jam, sebagai jaminan kepercayaan pasar tehadap produk yang dipasarkan. Target dibawah 3 jam diperhitungkan dengan mempertimbangkan produksi berada dalam kota ambon dan pemasaran pun berada dalam kota Ambon.

Analisis Teknis/Operasi

1. Potensi Produksi Lempengan Keripik Biji Durian

Potensi Produksi Lempengan Keripik Biji Durian Dari Hasil Rajang Biji

\begin{tabular}{|c|l|c|c|c|c|}
\hline \multirow{2}{*}{ No Urut } & \multirow{2}{*}{$\begin{array}{c}\text { Nama } \\
\text { Durian }\end{array}$} & \multicolumn{2}{|c|}{ Ukuran Biji } & \multirow{2}{*}{ Berat/Biji } & $\begin{array}{c}\text { Jumlah } \\
\text { Lempengan }\end{array}$ \\
\cline { 3 - 4 } & Diameter & Panjang & & 6 \\
\hline 1 & Tuny & $2 \mathrm{~cm}$ & $3 \mathrm{~cm}$ & $0,01 \mathrm{~kg}$ & 6 \\
\hline 2 & Bangkok & $2,5 \mathrm{~cm}$ & $3,2 \mathrm{~cm}$ & $0,06 \mathrm{~kg}$ & 8 \\
\hline 3 & Bangkok & $2,6 \mathrm{~cm}$ & $3,4 \mathrm{~cm}$ & $0,07 \mathrm{~kg}$ & 9 \\
\hline 4 & Bangkok & $2,4 \mathrm{~cm}$ & $3,3 \mathrm{~cm}$ & $0,08 \mathrm{~kg}$ & 10 \\
\hline 5 & Bangkok & $2,3 \mathrm{~cm}$ & $3,5 \mathrm{~cm}$ & $0,09 \mathrm{~kg}$ & 11 \\
\hline 6 & Tuny & $2,1 \mathrm{~cm}$ & $2,9 \mathrm{~cm}$ & $0,02 \mathrm{~kg}$ & 7 \\
\hline 7 & Tuny & $1,9 \mathrm{~cm}$ & $2,8 \mathrm{~cm}$ & $0,03 \mathrm{~kg}$ & 8 \\
\hline 8 & Tuny & $1,8 \mathrm{~cm}$ & $2,6 \mathrm{~cm}$ & $0,04 \mathrm{~kg}$ & 9 \\
\hline 9 & Tuny & $2,2 \mathrm{~cm}$ & $2,7 \mathrm{~cm}$ & $0,05 \mathrm{~kg}$ & 10 \\
\hline 10 & Tuny & $1,7 \mathrm{~cm}$ & $2,5 \mathrm{~cm}$ & $0,06 \mathrm{~kg}$ & 11 \\
\hline \multicolumn{2}{|c|}{ Rata-Rata } & $2,15 \mathrm{~cm}$ & $2,99 \mathrm{~cm}$ & $0,051 \mathrm{~kg}$ & 8,9 \\
\hline
\end{tabular}

Rata-rata lempengan keripik/biji durian apabila dirajang dengan menggunakan alat potong seperti di tunjukan di bawah ini, didapat 9 lempengan keripik/ biji durian. Dengan demikian total produksi lempengan keripik biji durian/triwulam

$$
\begin{aligned}
& =757.550 \times 9 \\
& =\mathbf{6 . 8 1 7 . 9 5 0} \text { lempengan keripik biji durian }
\end{aligned}
$$


2. Proses Produksi Keripik Biji Durian

A. Bahan

Bahan Dasar : Biji Durian, Minyak Goreng, Minyak Tanah.

Bahan Pembantu : Garam, Bawang Putih, Kemiri, Cabe Merah, Gula Pasir,

Bahan Perendam Biji Durian : Kunyit, Kapur,

B. Peralatan Produksi

Alat Perajang, Baskom, Gekas Ukur, Kompor Besar, Plastic Pembungkus, Sendok Kayu, Sendok Makan, Tampah, Timbangan, Wajan

C. Tenaga Kerja

Sumber daya manusia tenaga kerja untuk jenis produksi ini tidak terlalu membutuhkan sumber daya manusia berpendidikan tinggi(sarjana), kalaupun memang tersedia tidak menutup kemungkinan untuk digunakan. Jumlah tenaga kerja disesuaikan dengan volume dan tahapan proses produksi dengan menggunakan metode yang diinginkan

D. Proses Produksi Keripik Biji Durian

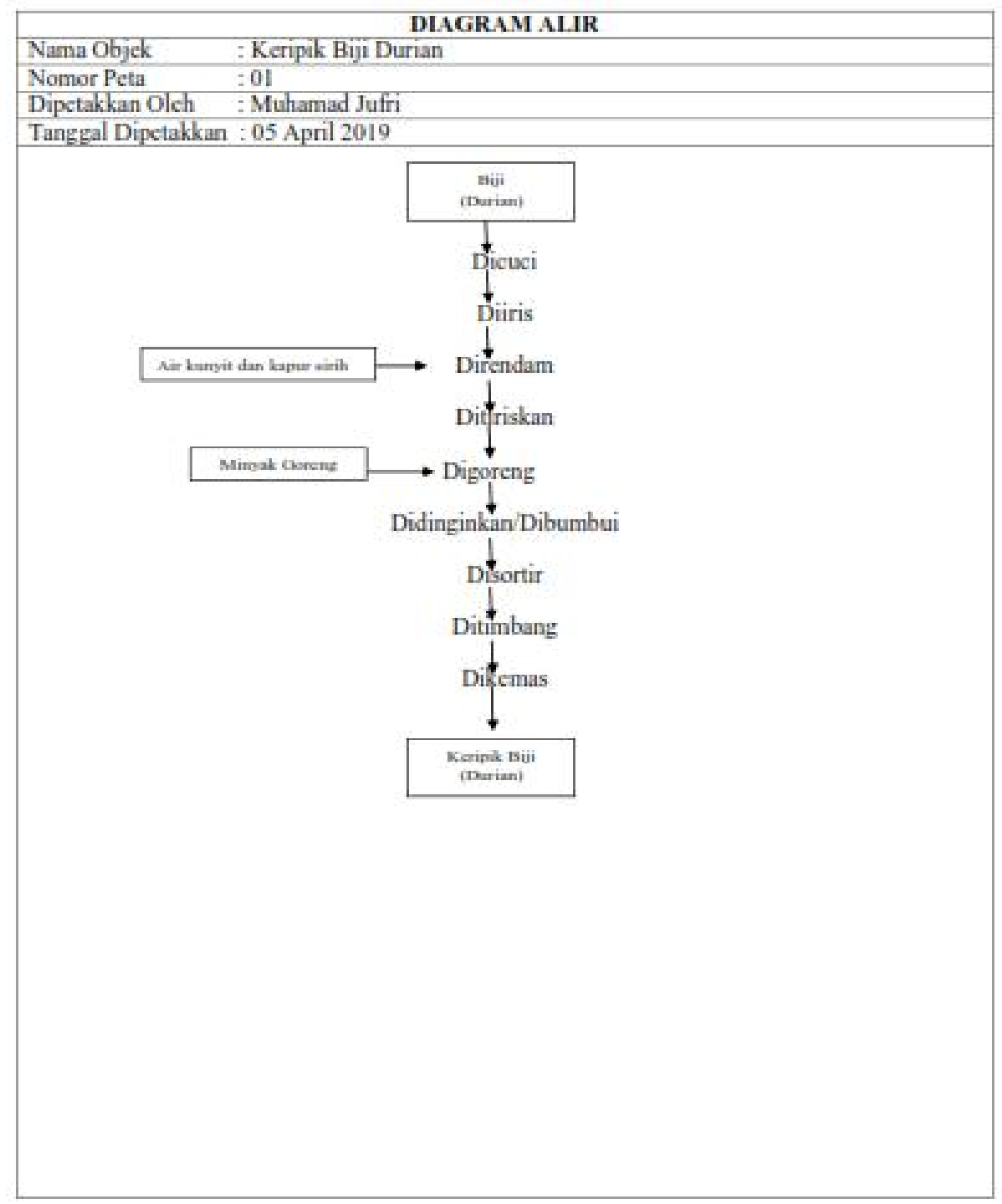

Diagram Alir Proses Produksi Keripik Biji Durian 


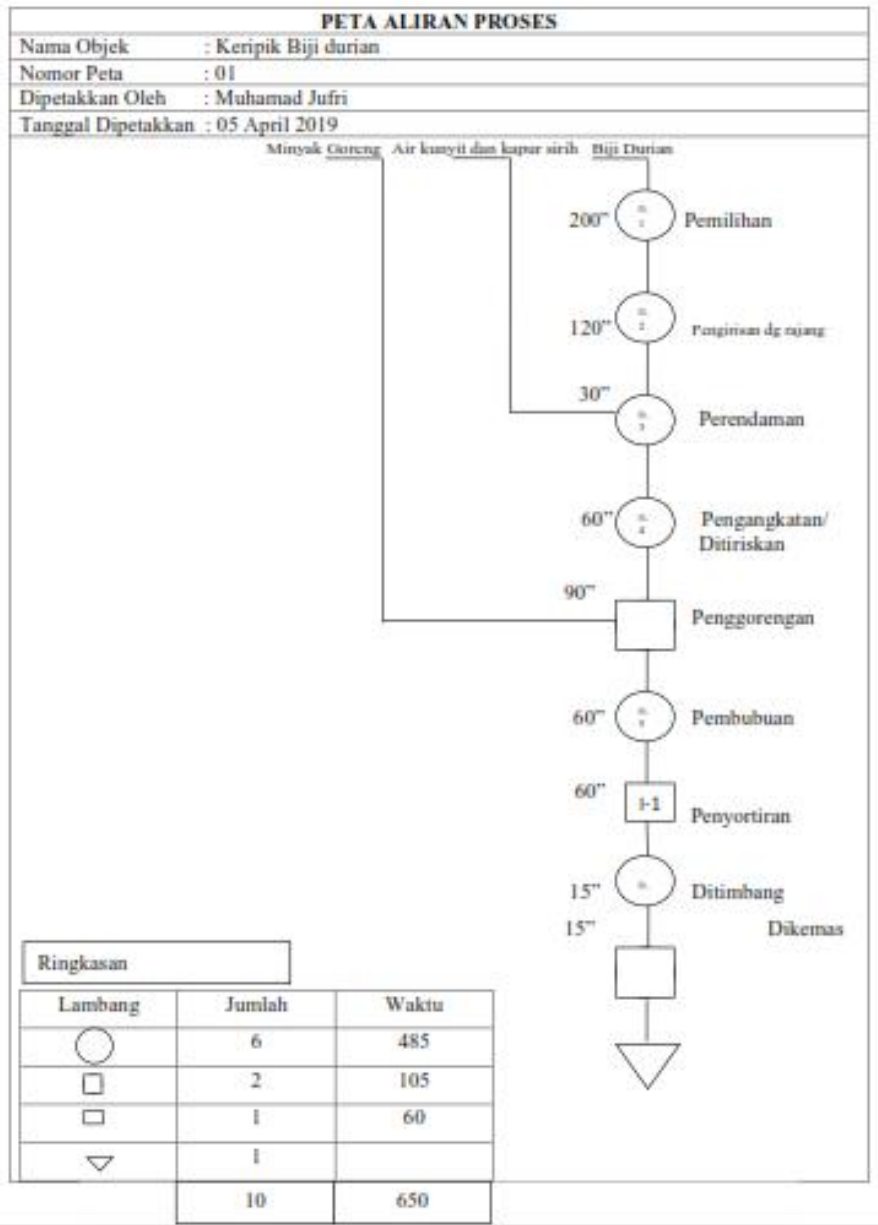

Peta Aliran Proses Produksi Keripik Biji Durian

3. Target Produksi Lempengan Keripik

Dengan menggunakan hasil analisa total biji durian/triwulan untuk pasokan dari pulau Seram dan produksi durian pulau Ambon, dimana total biji durian sebanyak $\mathbf{7 5 7 . 5 5 0}$ biji durian/triwulan atau 252.516/bulan. Sehingga analisa kebutuhan bahan baku utama biji durian tetap didasarkan pada potensi serapan pasar yaitu sebesar 69\% untuk keripik berbagai rasa (pedas,manis dan asin) hasil analisa pasar dari ke 7 wilayah pemasaran dalam kota Ambon, dengan memperhitungkan rata-rata isi lempengan keripik/saset adalah 10 lempengan maka kebutuhan bahan baku biji durian adalah:

$=($ Stok $1.310 \times 69 \%)+(10 \% \times$ Stok 1.310$)$ stok tambahan

$=903+131$

$=\mathbf{1 . 0 3 4}$ stok saset

Dengan hasil rajangan /biji rata-rata 9 lempengan maka didapat total kebutuhan biji durian

$=(1.034 \times 10) / 9$

$=1.148 \mathrm{biji}$ durian $/ \mathrm{minggu}$

Dengan demikian kebutuhan biji durian/bulan

$=1.148 \times 4$ minggu

\section{= 4.592 biji durian/bulan}

Dengan memperhitungkan rata-rata jumlah biji durian/kg yaitu sebanyak 40 biji, sehingga total kebutuhan berat bahan baku biji durian/bulan

$$
=4.592 / 40
$$

$=115 \mathrm{Kg} /$ bulan (dibulatkan)

Sehingga total lempengan biji durian yang dihasilkan per bulan yaitu:

$=4.592 \times 9$ 
$=41.328$ lempengan biji durian.

\section{Analisis Finansial}

1. Investasi/Modal Usaha

Investasi atau modal usaha diperuntukan untuk pengadaan peralatan produksi dan biaya operasional/produksi

2. Investasi Peralatan Produksi

Biaya Peralatan Produksi

\begin{tabular}{|c|l|c|c|c|c|}
\hline No. & \multicolumn{1}{|c|}{ Jenis Alat } & $\begin{array}{c}\text { Jumlah } \\
\text { Buah(unit) }\end{array}$ & Umur akai Alat(Bulan) & $\begin{array}{c}\text { Harga/Unit } \\
(\text { Rp) }\end{array}$ & $\begin{array}{c}\text { Total Investasi } \\
(\text { Rp) }\end{array}$ \\
\hline 1 & Alat Perajang/Slicer & 1 & 12 & 75.000 & 75.000 \\
\hline 2 & Sendok Makan & 4 & 12 & 2.500 & 10.000 \\
\hline 3 & Gelas Ukur & 2 & 12 & 5.000 & 10.000 \\
\hline 4 & Kompor Besar & 2 & 36 & 260.000 & 520.000 \\
\hline 5 & Sendok Kayu & 2 & 12 & 5.000 & 10.000 \\
\hline 6 & Pisau Pengupas & 3 & 12 & 3.500 & 10.000 \\
\hline 7 & $\begin{array}{l}\text { Meja pengering sinar } \\
\text { matahari }\end{array}$ & 4 & 12 & 300.000 & 1.200 .000 \\
\hline 8 & Oven Pengering & 1 & 36 & 3.750 .000 & 3.750 .000 \\
\hline 9 & Timbangan & 1 & 36 & 50.000 & 50.000 \\
\hline 10 & Baskom Plastik & 3 & 12 & 13.000 & 39.000 \\
\hline 11 & Wajan/Nyiru & 5 & 24 & 20.000 & 100.000 \\
\hline \multicolumn{2}{r|}{ Jumlah } & & 19.64 & 4.484 .000 & 5.774 .000 \\
\hline
\end{tabular}

3. Biaya Langsung

A. Biaya bahan baku

Biaya Bahan Baku Utama

\begin{tabular}{|l|c|c|c|}
\hline \multicolumn{1}{|c|}{ Nama Bahan } & Unit & $\begin{array}{c}\text { Harga/ } \\
\text { Unit(R) }\end{array}$ & $\begin{array}{c}\text { Total } \\
\text { Harga(Rp) }\end{array}$ \\
\hline a. Biji Durian & $102 \mathrm{~kg}$ & 1.000 & 102.000 \\
\hline b. Kunyit & $4 \mathrm{~kg}$ & 20.000 & 80.000 \\
\hline c. Kapur Sirih & $3 \mathrm{~kg}$ & 23.000 & 70.000 \\
\hline d. Minvak Goreng & $15 \mathrm{~L}$ & 16.000 & 240.000 \\
\hline e. Bawang Putih & $2 \mathrm{~kg}$ & 10.000 & 20.000 \\
\hline f. Kemiri & $1,5 \mathrm{~kg}$ & 20.000 & 30.000 \\
\hline g. Cili Merah & $2 \mathrm{~kg}$ & 40.000 & 80.000 \\
\hline h. Gula Pasir & $2 \mathrm{~kg}$ & 13.000 & 26.000 \\
\hline i. Garam & 500 gr & 2.100 & 10.500 \\
\hline j. Air & - & - & - \\
\hline Minyak Tanah & $30 \mathrm{ltr}$ & & 105.000 \\
\hline \multicolumn{2}{|c|}{ Jumlah } & 155.100 & 658.500 \\
\hline
\end{tabular}

B. Tenaga kerja produksi keripik biji durian

Jumlah tenaga kerja yang dibutuhkan untuk memproduksi keripik biji durian dalam kajian ini ditetapkan 4 orang dengan upah tenaga kerja disesuaikan dengan Upah Minimum Regional Kota Ambon yaitu sebesar 2.000.000/bulan, dengan demikian total Upah karyawan/bulan :

$=3 \times 2.200 .000$

= Rp 6.200.000

4. Biaya Tidak Langsung

A. Bahan pembungkus/saset

Jumlah plastik yang dibutuhkan untuk memproduksi keripik biji durian dalam kajian ini ditetapkan $10 \mathrm{~kg}$, dengan harga Rp 13.000/kg, sehingga total biaya pembungkus/saset adalah Rp 130.000/bulan

B. Biaya cetak label pada pembungkus/saset

Biaya cetak label sesuai harga pasar cetak label disesuaikan dengan jumlah huruf, besar huruf dan besar logo, dari hasil tanya jawab dilapangan terkait harga cetak label sesuai dengan model label dagang keripik biji durian yang dirancang ditetapkan seharga Rp 100/saset. Dengan demikian untuk kebutuhan saset/bulan sebanyak:

$=4.133 \times 100$

\section{$=\operatorname{Rp} 413.300 / \mathrm{bulan}$}

C. Upah tenaga kerja pemasaran/bulan

Tenaga kerja pemasaran adalah sebanyak 1 orang untuk mengantarkan hasil produk ke 7 wilayah pemasaran setiap hari dengan menggunakan kendaraan bermotor roda dua. Upah tenaga kerja pemasaran adalah sama dengan upah tenaga kerja produksi langsung keripik durian yaitu sebesar Rp.2.000/bulan sesuai UMR Kota Ambon. 
D. Biaya bahan bakar kendaraan pemasaran/bulan

Total biaya bahan bakar untuk operasional pemasaran sesuai dengan luas wilayah pemasaran ditetapkan:

$=4 \times 20.000 /$ bulan

$=$ Rp.80.000/bulan

E. Oil/oli

Penggunaan oli untuk kendaraan pemasaran/bulan 0,8 liter dengan harga Rp35.000/bulan

F. Biaya promosi

Promosi/reklame produk keripik biji durian akan digunakan cetakan selembaran dengan cara print out dengan menggunakan kertas data print biasa(A4) dengan hasil cetakan berwarna ditetapkan sebanyak 7 × 9 × $10=360$ lembar/bulan. Dengan demikian kebutuhan biaya untuk lembaran reklame diperkirakan Rp.100.000.

Promosi ini dengan cara dibagiakan atau ditmpelkan/wilayah ke sasaran pasar yaitu tujuh wilayah sasaran pasar dalam kota Ambon dengan cara menempelkan pada lokasi-lokasi yang mudah terbaca setelah, terlbeih dahulu memohon ijin kepada penguasa (RT,kios, maupun dinding rumah).

G. Tempat usaha

Tempat usaha keripik biji durian untuk mengurangi biaya produksi yang dapat mempengaruhi harga jual hasil produk maka tempat produksi akan di gunakan langsung rumah pemilik usaha, dengan demikian dikatakan home industri. Sehingga biaya tempat produksi dalam analisa ini ditiadakan.

5. Rekapitulasi Total Biaya

A. Biaya langsung
a) Biaya Bahan Baku
b) Tenaga kerja Produksi
$=$ Rp. 658.500
$=$ RP. 6.000 .000
Total Biaya langsung
$=$ Rp .6.658.500

B. Biaya tidak langsung
a) Bahan pembungkus
b) Cetak label
$=$ Rp. 130.000
$=$ Rp. 413.000
c) Upah tenaga kerja pemasaran
$=$ Rp. 2.000 .000
d) Biaya bahan bakar kendaraan
$=$ Rp. 80.000
e) Oil/oli
$=$ Rp. 35.000
f) Biaya promosi
Total Biaya Tidak Langsung
C. Total Modal Peralatan
$=$ Rp. 100.000
$=$ Rp. 2.758 .300
= Rp. 5.774.000

Dengan demikian total modal usaha/invstasi yang dibutuhkan adalah sebesar Rp.15.190.800

Total modal usaha ini akan dipinjamkan dari Bank dengan besar suku bunga pinjaman sebesar 1,20\%/bulan, dengan demikian biaya modal/bulan:

$=\mathbf{1 5 . 1 9 0 . 8 0 0} \times \mathbf{1 , 2 0 \%}$ ( Panin Bank 2018, Untuk pinjaman $<100$ juta $)=$ Rp.182.289/bulan

6. Harga Pokok Produksi

Harga jual/saset didapat dari total biaya/total produksi( saset)/bulan:

$=(\mathbf{1 5 . 1 9 0 . 8 0 0}+\mathbf{1 8 2 . 2 8 9}) /$ total saset/bulan

$=15.373 .089 / 4.133$ saset

= Rp. 4.000 (dibulatkan)

7. Harga Jual Ideal

Harga jual ideal Untuk ke tiga rasa keripik biji durian (pedas,manis, dan asin) adalah sama, dengan

presentasi keuntungan/saset adalah sebesar $50 \%$ dari harga pokok produksi/saset:

$=(50 \% \times 4.000)+$ harga pokok produksi $/$ saset

$=\operatorname{Rp} 2.000+4.000$

$=\operatorname{Rp} 6.000 /$ saset

Total pendapatan kotor/bulan sebelum dikurangi biaya produksi/bulan adalah:

$=4.133 \times 6.000$

= Rp. 24.798.000

8. Laba Rugi/Bulan

$=$ Pendapatan kotor $-($ biaya langsung + biaya Tidak langsung + modal $)$

$=24.798 .000-(9.599 .089)$

$=$ Rp 15.198.911 
Dengan memperhitungkan pajak penghasilan(pph sebesar 11\%) maka total pendapatan bersih/bulan:

$=15.198 .911-(11 \% \times 15.198 .911)$

$=15.198 .911-1.671,21$

= 15.197.239 ( keuntungan bersih/bulan)

9. Titik Pulang Pokok

$\mathrm{Q}=\underline{\mathrm{TFC}}$

( $\mathrm{P}-\mathrm{TV} / \mathrm{unit}$ )

Dimana biaya tetap $(\mathrm{TF})=$ Upah tenaga kerja + bunga bank + biaya penyusutan $/$ bulan $=\operatorname{Rp} 8.000 .000+181.733+287.700$

$=\mathrm{RP} 8.469 .433$

$\mathrm{Q}=\underline{8.469 .433}(6.000-236)$

$=\underline{8.469 .433}$

5.764

$=1.469$ saset (titik pulang pokok)

Titik pulang pokok atau titik pulang modal usaha terjadi pada total produksi 1.469 saset. Dengan demikian sisa total produksi 2.664 adalah keuntungan.

10. Waktu Pengembalian Investasi

$$
\begin{aligned}
& \mathrm{Pb}=\mathrm{I} \\
& (\mathrm{b}-\mathrm{C})+\mathrm{D}
\end{aligned}
$$

Ket: $\mathrm{I}=$ Investasi $/$ modal usaha $=15.190 .800$

$\mathrm{B}=$ pendapatan kotor $\quad=24.798 .000 /$ bulan

$\mathrm{C}=$ Biaya Operasional $\quad=9.552 .133$

$\mathrm{b}=$ Pendapatan bersih $\quad=$ Rp 15.197.239

$\mathrm{D}=$ Nilai Penyusutan $\quad=287.700 /$ bulan

= Rata-rata umur pakai peralatan 20 bulan dengan nilai sisa Rp20.000( Harga besi tua, kompor dan oven. Dengan demikian nilai depresiasi/bulan

$=5.774 .000-20.000 / 20$

$=$ Rp. 287.700

$\mathrm{Pb} \quad=\quad \mathrm{I}$

$(\mathrm{b}+\mathrm{D})$

$=15.190 .800 /(15.197 .239+287.700)$

$=15.190 .800 / 15.484 .939$

$=0,99$ atau $=\mathbf{1}$ bulan

\section{KESIMPULAN}

Berdasarkan perancangan, pengujian dan analisis yang telah dilakukan, maka dapat disimpulkan sebagai berikut :

1. Perencanaan bisnis keripik biji durian merupakan usaha yang memproduksi keripik. Satu hal yang menjadi kelebihan bisnis baru ini adalah keripik biji durian belum ada di masyarakat sehingga dapat memberikan referensi baru pada masyarakat tentang cemilan dari biji durian. Perencanaan bisnis ini akan dijabarkan dengan beberapa aspek yaitu aspek pasar dan pemasaran, aspek teknik dan aspek keuangan. Di dalam aspek pasar dan pemasaran, bisnis keripik biji durian ini memiliki target pasar adalah semua kalangan yang menyukai produk olahan keripik biji durian dengan range umur 5-60 tahun dan bertempat tinggal di Kota Ambon. Pemasaran bisnis keripik biji durian ini berawal dari menawarkan ke kios kios, warung dan toko-toko sembako yang berada di wilayah pemukiman seuai dengan stok/pasokan yang diinginkan oleh masing-masing kios,warung atau toko cara lain pemasaran memposting di media sosial seperti Facebook,instagram dan WA. Harga yang ditawarkan untuk produk keripik biji durian ini Rp. 6.000/saset sehingga masuk ke kalangan menengah ke atas. Di aspek teknik/operasi, usaha keripik biji durian menggunakan rumah pemilik usaha sendiri yang berada di desa ahuru, Ambon. Dengan kapasitas produksi 65 saset/kios.

2. Sementara untuk aspek keuangan sendiri penilaian dari BEP dan PI dinyatakan positif sehingga usaha layak untuk dijalankan. 


\section{DAFTAR PUSTAKA}

Ali I, (2013)., Kandungan Gizi Biji Durian., (http://manfaat.org). Diakses 23 Maret 2018.

Anonim, 2009 Wikipedia Bahasa Indonesia, 2010. Ensiklopedia

Bebas(http://www.wikipedia. org. id/). Diakses 19 Maret 2013.

Bakti B, (2012). Manfaat Biji Durian.(http://manfaat.org). Diakses 23 Maret 2018.

Bima, (2012). Khasiat Biji Durian, UGM, Yogyakarta. Diakses 26 Maret (http://herbaten.com).

Febriani, I. E. (2005)., Pembuatan Kue Telur Blanak dari Campuran Tepung Beras Ketan dan Tepung Biji Durian dengan Rasa yang Berbeda. Tugas Akhir. Jurusan Teknologi Jasa dan Produksi. Fakultas Teknik Universitas Negeri Semarang.

Hamdin, (2012)., Khasiat Biji Durian, UGM Medan. Diakses 26Maret 2018.(http://klikunic.net/)

Tambun, (2012)., ManfaatBiji Durian, Natuna, Indonesia.Diakses 26 Maret 2018.(http://klikunic.net/)

Kristina. (1985)., Pembuatan Keripik (Chips) Biji Durian (Durio sp.) Tugas Akhir.Jurusan Teknologi Pertanian. Institut Pertanian Bogor.

Mahdi, (2006)., StudiKemampuanBiji Durian Sebagai Bahan Pengikat, Di akses 28 Maret 2018.(http://herbaten.com).

Moh. Djaeni, A. P, (2010)., Kelayakan biji durian sebagai bahan pangan alternatif : aspek nutrisi dan tekno ekonomi. Di akses 25 Maret 2018. (http://eprints.undip.ac.id/39242/1/kelayakan biji durian)

Rizka S A T (2017)., Perencanaan Bisnis Jus Pala. Fakultas Teknik Industri. Universitas Pattimura Ambon.

Rukmana, (1996)., Kandungan Gizi Biji Durian (http://id.wikipedia.org/wiki/durian.html). Medan. Diakses 27 Maret 2018.

Rukmana,(1996)., SpesifikasiBuah Durian.USU Medan. Diakses 3 Maret 2018.

Setiadi, (1999)., Tanaman Durian,: (http://manfaat.org). Medan. Diakses 27 Maret 2018

Sulistyowati, (2000)., Membuat Keripik Buah dan Sayur, EdisiPertama, Penerbit Puspa Swara, Jakarta.(www.pangupodit.com). Diakses 28 Maret 2018.

Umat S, (2013)., Kandungan Gizi Biji Durian.(www.pangupodit.com). Diakses 28 Maret 2018.

Wibowo A (2011)., Rencana Bisnis Industri Manisan Stroberi. Fakultas Teknologi Pertanian, Departemen Teknologi Indutri Pertanian. 
